\title{
Matergraphy and Heritage: Marian Shrines as Symbolic and Vector Spaces of Latinity
}

\author{
Christian Dennys Monteiro De Oliveira \\ Universidade Federal do Ceara, Fortaleza, Brazil \\ Email:cdennys@gmail.com
}

How to cite this paper: De Oliveira, C.D.M. (2017) Matergraphy and Heritage: Marian Shrines as Symbolic and Vector Spaces of Latinity. Open Journal of Social Sciences, 5, 185-206. https://doi.org/10.4236/jss.2017.510016

Received: September 17, 2017

Accepted: October 24, 2017

Published: October 27, 2017

Copyright $\odot 2017$ by author and Scientific Research Publishing Inc. This work is licensed under the Creative Commons Attribution International License (CC BY 4.0).

http://creativecommons.org/licenses/by/4.0/

(c) (i) Open Access

\begin{abstract}
This article develops the transformation of studies on Brazilian shrines, based on the Catholic invocation of Our Lady of Conception (Conceição Apareci$d a)$, in a cultural reflection on the notion of the symbolic space in Latin America. Considering the expressive historical, semiotic, and institutional aspects of Latin America's cultural heritage, this study recognizes the emergence of a network of identification for religious spaces. A geography of cultural projection that helps to articulate the interpretation of symbolic vectors (in festivals, media, and tourism), facilitates both comparison with other localities (municipalities-shrines) in Brazil and Latin America, and the characterization of the theatrical aesthetic of devotion in the construction of continental heritage. Summarizing the qualitative verifications made during three years of research on strategies to irradiate devotion to the Virgin Mary, this study achieved an aesthetic strength evaluation of religious patrimony as a challenge to systems of the heritage of Latinity. We concluded that the greatest risk to religious cultural patrimony lies in the growth of fundamentalist ideologies, which seek to discredit the legitimacy of the Marian tradition, and the religious and cultural syncretism in continental identity.
\end{abstract}

\section{Keywords}

Symbol, Marian Devotion, Catholic Shrine, Latinity, Religious Heritage

\section{Introduction}

I Think and Exist. Therefore I Study was Gaston Bachelard's maximum response [1] to his predecessor Rene Descartes, author of I think. Therefore I am. Although we can scarcely observe the kilometric distance between these and many other genius thinkers of the scientific theories' process, by virtue of the mere natural right to imagination-a pulse as delirious and bold as mythical human 
existence-I would respond to these select thinkers with the maxim: I Study the Geographical Space. Therefore, I Symbolize it.

The symbolic construction of space allows us to identify selective places, especially those endowed with brands and identifications that differ from the banal condition: Cities, valleys, mountains, protected areas, forests, commercial zones, neighborhoods, or coasts-an entire locational denomination can constitute this kind of "white paper", a generic graphical assumption over which there is an intentional drawing. Moreover, this drawing, humanely endowed with the artifice of remaking nature into culture, comprises the creative act of engendering meaning, or, in a similar metaphor, of communicating to the navigators that an ice island is submerged beneath the huge tip of the iceberg. But by what measure does each symbolic place that we study under this redesigned "shrine" condition correspond to this significant iceberg? Furthermore, regarding the identification of territorial delimitations, how can a city be promoted to the status of a post-modern shrine, aggregating traditions and innovations in its weave of vectorial forces?

Right from the outset, we must clarify that the idea of a "vectorial force" deploys a modern physics metaphor to describe the theatrical composition of the events that characterize the functionality of a place. Our acceptance of the term "symbolic vector" emerged from a semiotic reading of the scenic shows by critic and play writer Patrice Pavis [2], when he proposed the conditioning triad of time, space, and action in the analysis of theatrical events, and his mobilizing interdependence (on the chronotope, inspired by the contextual theory of $\mathrm{M}$. Bakhtin), which the author dubs "moving space vectors."

The response indicates mechanistic ideas when we consider the founding act of naming (differentiating) each of those "generic" spaces mentioned above, besides all the others that we could possibly imagine, as a preliminarily accessible example of geographical space: capital cities, historical cities, military cities, lost cities. There is, therefore, a specific sense that precedes generalization. Similarly, valleys (agricultural, swampy, planned, or of combat) can also qualify, more or lessas representative of human experiences that justify (select) such nominations. From this, we have created the foundation of the place in the path of specification, in creating a scenery that (re) memorizes a scene, or a set of scenes that mark this scenery better.

It is along this track that space finds the movement of time (geological, geomorphological, and anthropic, therefore, cultural), thus freeing itself from the constrained determinisms of fixture (always more enjoyable for general designs) and assuming the contemporary parameter of specific fluidity. Which cities, which valleys, which elementary events configure a theatrical celebration of the geographical, externalized on a geographic symbol? In other words, similar to geography, in its cultural nature, what becomes "matergraphy" before acquiring a theatrical dimension and decoding into patrimoniality?

The starting point is, with all the doubts that Cartesianism renews in the bachelardian way of thinking and feeling, the broadening of the "shrine" concept, 
of symbolic and vectorial space, motivator of a diversity of events that are activated by the power of the world's religious reading. The place-specific space, which we well or averagely "know" through the attribution of meaningspermanently correlates with spaces of ignorance. Light and shadow, sound and silence, flavor and feeling, touch and will, sacred and profane associate to move Earth's space/time, through design (graphic and imaginary), and correspond to my/your/our search for meaning. A shrine can therefore constitute this profusion of ambiguous feelings, previously connected by the mythical projection that religious communication systems welcome. This kind of study is based on philosophical approaches, that are more open to interactive subjectivity-particularly phenomenology, existentialism, and hermeneutics-and follows process of scientific learning, according to humanist geographers such as Eric Dardel, Edward Relph, Yi-Fu-Tuan, David Lowenthal, Giuliana Andreotti, Anne Buttmer, and Lívia de Oliveira-on Marginal Geographies, as SaleteKozel's [3] reading suggests.

So-called shrines-originating in the religious field-are, in fact, symbolic representative places from the spaces lived and the experiences in their scenic temporality [4]. We will, based on a purely educational motivation, move from the fixed formulations of traditional religious, urban-metropolitan technology, landscape, or natural ecology constitutions in order to approach the creative kinetics of shrines. Artistically, the fluid constitution of a shrine as a "manifestation" or as a "coronation" party, forges a chronotropic wedding between space and time, and vice-versa. In the words of Lucrécia Ferrara [5], it is about glimpsing the active determinants in time/space as a symbol, capable of reuniting, communicating, and approximating a habitat from an eventuality. She says:

In the first decades of the twentieth century, Bakhtin looked to face this challenge, and with sharp sagacity, he foresaw the future that was already starting to impose the need to pay attention to the nature of the way in which time was the architect of daily life. As a possible response to this challenge, Bakhtin created the concepts of polyphony and dialogue, which recover the long duration of the construction of mentalities of culture and the semiotic space of expanding manifestations, creating a logic macro trend... [5]

We then recognize a geographic/semiotic interface of the shrine, because of its signification as a scientific object, which challenges new ways of time-space ordering. Later, at the closing of this brief journey, we will see how the matergraphy of the shrine leads us to re-adapt the polyphony and dialogue, in qualitative research about the patrimonial communication adapted to the understanding of the religious space. First, however, the recurring concept of "sacred", in its organicity, needs to be better delimited.

\section{Problematization}

No shrines are forged in the functional exclusivity of a single sacred role. The discretionary interpretation system adopted by Mircea Eliade [6] for the comprehension of pre-modern mythical man, didactically separates a sacred core 
(identified as mono) from its many "profane" surroundings (identified as mult). This separation not only can but must favor the photographic instant of a more dynamic film. The sacredness, as the "bellybutton" or "axis" of the world, only emerges as a ritual reverence of the celebrations if, and only if, all non-ritual moments and places cooperate in its profanity. This expression is much better understood in the sense of "preparation" than that of "negation" or "offense", precisely to facilitate the performance of that sacred project.

This will all surely be valid when we ignore marginal sacredness, that is, sacredness that is not hegemonic or subordinated. This is commonly the case when the "sacred" is reduced to the classic monotheist religious systems: Judaism, Christianity, Islam [7]. The sacredness of the profane universe also provides special times/spaces, which are relatively complex and deserving of the repositioning of the axis mundi. This is particularly the case in modern societies that incorporate multiple traditions and aggregate new rites and myths in their religious compositions. Exactly because of these new "compositions", we begin to observe the diffusing power of shrines in non-traditional models in the ritual, urban, and natural spaces, beyond the referring agricultural-livestock constitution that is so remarkable in Brazilian colonial formation. The post-colonization that was lived at the beginning of the twenty-first century, as we know through investigation and social experience, has gained new and diversified tessitura in the specific religious field, or even in the secular field, consolidated by overlapping crises and multiple information systems. The immediately resulting process of this tends to lead to the emergence of new religiosities, either in politics, law, artistic culture, science ethics, philosophy, or technology.

We have reached this broadening of the religious field through symbolic elements designed in patrimonial space. Such elements awaken a unique possibility in cultural geography research, which we would now like to develop, promoting them as the source of new investigations for study projects through partnerships. The Marian Shrines in popular Catholicism outline a dynamic in response to the Jewish tradition: It is no longer about updating Israel's Semitic nomadism, contemporarily established in the wake of Universal Human Rights achievements [8]. Such targeting has been fed by the myth of the "chosen people" and the search for the "promised land", by which means the transformation of a mobile alliance (unstable) in the great static temple (stable), located in Jerusalem, was promoted.

Rather, it is about re-composing an entire mythological saga, based on the interpretation that Christianity rose on two urban pillars: Jerusalem and the Other City, conquered as "holy", i.e., Rome or its terrestrial similar. Both connect many places and people, based on the challenging idea that there are multiple arks of the covenant, both human and planetary. Therefore, if Judaism forged its "heritage" to the Western religious system, a primary paternal legacy when we think of the Greco-Roman traces of Christianity, we should now visualize its maternal counterpart. Its counterpart is seen as "secondary" when we limit ourselves to considering this paganism, a syntax of infinite ethnic/regional pagan- 
isms, forged over almost 1600 years if one counts from the time of Constantine's conversion from Emperor to Pope of Rome, as the referential process for the hegemony of Christianity.

The proposal here is diametrically opposed, because, in a certain way, in Popular Religiosity, Paganism has maintained its hegemony in considering that the continental enterprise conventionally called "Latin America"-both in its majoritarian Iberian colonization and in the French-Dutch or Anglo-Saxon contestation-has, in fact, lived the inversion of the mainly pagan matrix, always grounded in multiple holy sites. Here, the paternal bond to old Jerusalem has never been so relevant, although we must reconsider this distance (as relatively smaller) when the renewed international interests of Protestantism are examined, especially from the perspective of the neo-Pentecostal imaginary. We remember, particularly, the liturgical and discursive use of the heroic episodes of the Old Testament and the modes of cinematographic and architectural representation of the Universal Church of the Kingdom of God (UCKG), with mega touristic enterprises, such as Solomon's Temple in São Paulo.

A complex profane/pagan matrix of Christianism allows us, therefore, to find on many shrine models the "Latin" symbolic mode of construction, redesigned for the American continent. Usually, such matrices considered are from the defensive perspective, as corresponding to the exclusive condition of a victim of the colonization process. The indigenous and African descendant traditions, besides the relevant ethnic minorities, considered are without responsability by colonial history, based on the logic of popular Catholicism. However, for the conquered peoples, the colonial process is interdependent and more complex. This extreme West (for it is interesting to consider it in this way), with its growing focus on immaterial assets, brings its sociocultural knowledge to the light of an infinite mix of cultural sources. Due to the unfolding of the geographical space of the religious field, it is necessary to acquire specificities that settled are in this matrix logic. Here, geography is recreatedas "matergraphy", to expand its previous scientific knowledge with the language of approximation of different pieces of knowledge. Matergraphy is a way of saying that the cultural and religious geographies have an expressive "gift" of producing goods and services, rooted in the diversity of experience of various peoples [9]. Especially, when such peoples do not dispose of the history of achievements, which could more effectively empower them than the acknowledgment of their right to existence would do. This is the socio-environmental reality that we typify as examples of models of Marian shrines in Latin America.

We will initially have as an exposition reference, the three models of devotional network on a national scale, moving from the Brazilian reality, with its shrines of different magnitudes-Aparecida, in the state of São Paulo, completed by its territorial area of diocesan irradiation; Belém, the capital of the state of Pará, projected in its great regional festivity; and Juazeiro do Norte, in the South of Ceará, cultivated in its pilgrim resistance tradition. 
In examining this first item, we will frequently look to demonstrate the Latin American equivalencies, with their national trademarks, festive or popular, that can translate the "traditional" shrine model. We will simultaneously point out the predominance of a greater or lesser balance in the dynamic of symbolic vectors of devotional irradiation.

In the second part, we will work on the characterizing exposition of these vector forces, in terms of their communicational nature or, as we prefer to call them, "geo-educational." We use this term, as it is possible to re-learn the ways of knowing of geographic spaces in the metaphoric game between three hierarchic levels of appreciation of immaterial assets. Initially, the deepest ones, or "mythical-religious", which project our rituals and update the religious practices in carnivalization aesthetics. Sequentially, at the intermediate level, there are those exchange levels that translate the languages of nature into the languages of the environment. We call these "mediatic-ecosystemic" vectors, which correspond to advertising aesthetics. Finally, in the most superficial plan, the last vector forces, "political-nomads" or "political-touristic", which represent the other spheres that model the terrestrial externality, as a cultural planet, and in this sense, as a mobility and permanent change aesthetic.

To simplify, in order to comprehend such forces as shrine molders in a measurable spatial segment-here called a municipality-shrine-we will re-name the vectors according to their main derivative. The first is manifested by Ritualization. The second by Mediatization; and the third by Visitation. Therefore, the "ritualizing" festivity, the "mediatizing" advertising, and the "visiting" tourism represent, in this study, three communicational (and geo-educational) energies of the establishment of the symbolic space of shrine municipalities. The examples in this project directly emerge from the studies performed, with the group of municipalities devoted to the invocation of Conceição Aparecida, whose diocesan hierarchy transformed into regional shrines, thus defying the sometimes collaborative and sometimes competitive action of the three vectors.

Finally, to close the project, we directly approach the conception of the religious heritage or emerging patrimonialism of this Marian devotional design. This is precisely because, by default of the cares of secularism and the public domain of religious culture, a confluence of controversy causes the acknowledgment of a Republican "religious matter", which is far from being resolved, to overflow. Exactly that which should translate the multiple assets of popular $\mathrm{Ca}$ tholicism into cultural heritage; however, it "reduces" (rather than translates) it into a complex game of tensions between growing and resistant liturgical practices. Either they are Christian, non-Christian, or anti-religious. All suffer the growth of more or less fundamentalist processes, including the reading of the Marian devotion itself as a type of Catholic counter-reformation.

In this sense, it will be extremely worthwhile to show that the continuity of investigation of the role of the Marian patron saints in the universe of countries on the continent-including the so-called Anglo-Saxon nationalities-coincides with a re-orientation of international cultural policy. Whatever the role per- 
formed by their religious heritage on American nations, the confessional transformations (within or outside of Christianity), and the weight of modern education on the social formation of youth, the transit between Marian devotion and consciousness of the vulnerabilities of the terrestrial nature can no longer be ignored. Exactly for that reason, the reading of geography as "matergraphy" resizes the existing space to study its symbolic flows. There, on the shrines, where we acknowledge the matergraphic origin, we also notice the patrimonial tensions.

\section{Brazilian Marian Shrines: Three Vector Models}

As indicated in the introduction, reading popular religiosity from devotion to representations of the Virgin Maryconsolidates a fundamental dialogic movement to the strengthening of Christian traditions in the context of the general secularization of society. Within the Latin American and Brazilian scope in particular, this immediately translates into the unlimited multiplication of Marian invocations. In other words, it does so by molding the image of Mary, Mother of God, through the plasticity of motivational signs that are capable of mirroring "Marys" as diversified as the infinite Daughters of God. That is, the most feminine of the divine expressions of Christianity is the natural radiance of the most unlimited tendency to amultiplicity of representations.

Moreover, the Marian representations, in local and historical contexts, can be understood as merely a didactic adaptation of the negotiation between Catholic expansion (even postcolonial) and the submission of the faithful, who are "passively" dependent on a human image committed to a more concrete or immediate material functionality. Are they: The Lady of Sorrows (to soften our woes), the Lady of Help or Relief (to help us), the Lady of Hope (to revive us), the Lady of Grace (to grant us such), amongst many other Ladies, not to mention the saints who are as or more committed to making this multiplication of Ladies express a collective of intentions. When not considering the compensations of one or another auxiliary of God the Father, who failed or was not properly, understood, localities recognized as centers of Marian devotion, based on the traditional invocation of the Aparecida Conception, tend to maintain this same principle. The idea that the presences of the Virgin, in her Immaculate Conception, show us that abundance and fertility are possible, even in a world of ostensible scarcity.

This work considers the integrated reading of 37 Marian shrines, created by the association of direct invocations of the Mother of God in Catholic Christianity, such as the Immaculate Conception or Conception (more commonly used). One of these invocations in particular-that of the virgin Aparecida-is known as capable of synthesizing this overcoming of the natural or social limits of the divine intervention, as visible (Aparecida) and miraculous (the virgin pregnancy). This is because, besides the main shrine $\left(38^{\circ}\right)$ in the city of Aparecida (174 $\mathrm{km}$ from São Paulo), these smaller or more regionalized shrines facilitate a family-level, community-level, or local-level devotion by expanding the religious representation of such localities. 
Marian devotion contemplates the most substantive and concrete local modulation of the Christian faith pedagogy, which has great abstract appeal. The Holy Trinity, a complex of Roman Catholic mysticism that "explains" the correlation between the figures of God the Father, the Incarnate Son of God, and the Holy Spirit, opens an intellectual space for an extensive theology of the religious system that endorsed what we call the Western World. However, this complex escaped the multiple adaptive influences of peripheral peoples ("barbarians", "aborigines", "indigenous", and "blacks of the earth"), who depended on both regional and local deities to negotiate the significant learning paths of this abstract and distant faith. Visual and tactile sensibility, channeled through the figurative pedagogical exercise of Christian icons, through substantive images of Divinity/Humanity mediation in the figures of the saints, promoted the passage from "explanation" to "implication." To implicate is to compromise, to involve, endowing belonging to obligations when apparently, only physical-material property is seen [10].

The theologian Alfonso Murad [11] reminds us, in his study of the theology of the image in the iconography of the Mother of God, of the troubled history of the negation and affirmation of the Marian religious icon in the faith content construction system. He says:

Strictly speaking, icons are not painted but written. This would be as the Sacred plastic scripture, in an image. From there comes the term iconography (which means writing icons), and iconographer (the writer of icons). This is an appreciated vocation in the western church, which implies serious responsibilities and proper spiritual preparation [11].

The transposition of this process to the West went through a troubled phase of historical pulsing on the edge of Renaissance modernity, as rearranged by baroque aesthetics. The two-dimensional system gained a higher meaning in the tridimensional models of the saints and Virgin Mary's, which were projected from the flags of processions and caravels to gain the form of statues, homemade or institutional. The shrines used as Marian models in this study on a national scale-Aparecida (SP), Nazaré (PA), and Dores (CE)-express this moment of achievement and resilience of a Brazil and America, in being submitted to modernization in terms of ways in which to write this Christian icon.

A vectorial exercise of symbolic construction, of the integration of different sacred-profane places, demands that integrating criteria be selected. We considered as "sacred-profane" the fixed or eventual (festive) locations that represent the confluence of religious interest in the dialectics of the approximation/isolation of mundane values. By that means, as opposed to conventional dichotomous approaches-willing to directly correlate religious with "sacred" versus non-religious with "profane"-we preferred to advocate the perspective of a tactical response to the marginalized experiences recognized by Michel de Certeau in his study The Invention of the Daily Life: The Arts of Making [12]. Opposing tactic to strategy (sacred), he says: On the opposite, by the fact of its non-place, the tactic depends on the time, watching to "capture in the flight" the possibilities of gain. 
It does not keep what it wins. It has to constantly play with the events to transform them into occasions [12].

The tactic is existential. Therefore, vectorial logic allowed us to treat the national/regional and reticular moving scales as associative spatial ways: Where and how does an expressed Marian devotion establish a territory of cultural diversity? With investigation projects underway with regard to devotional irradiation, looking to display the unequal coverage of the invocation of the Immaculate Conceição Aparecida on a national scale, we look to two other Marian ways that can represent the two other scales. By this means, and in summary, we reached the following syntax board of this Brazilian projection of the three models (Figure 1), and from them, opened up ways to comprehend the potentiality of the time-space and symbolic formation of what will be approached in the next item: the shrine-municipalities.

Devotional irradiation is founded on the globalization of Christianism, and its elementary sustenance trademark appears in the theological exercise of "evangelization"; or, in prophetic terms, in the annunciation of Christ's New Testament, through multiple languages or ways of broadcasting the message to the many peoples on Earth. The temples that arose as "transmission towers" tended to propagate such "good news" (gospel) on a wider scale, beyond the limits of the Church. The effect of this transmission network on contemporary ecclesial spatiality domains (dioceses, provinces, and Episcopalian regions) is national-scale projection on the regional level. We may then think of the classic groupings of Brazilian socioeconomic territories (South-Central, Amazon, and Northeast) as a corresponding delimitation of the three symbolic vectors, with which we identify the empirical base of our studies: the shrine municipalities.

\begin{tabular}{|c|c|c|c|}
\hline MODELS & SCALES & $\begin{array}{l}\text { MOST RELEVANT } \\
\text { SYMBOLIC VECTORS }\end{array}$ & $\begin{array}{l}\text { DEVOTIONAL } \\
\text { SPACIALITY }\end{array}$ \\
\hline Conceição de Aparecida & \multirow[b]{2}{*}{$\begin{array}{l}\text { Supra Region } \\
\text { of Brazilian } \\
\text { South-Central }\end{array}$} & \multirow[b]{2}{*}{$\begin{array}{l}\text { Political-Tourist (of } \\
\text { Visitation) due to the } \\
\text { reproduction in } \\
\text { quantities of Shrines } \\
\text { (38) and parishes (+ of } \\
\text { thousand) }\end{array}$} & \multirow[b]{2}{*}{$\begin{array}{l}38 \text { Municipalities- } \\
\text { Shrines. Spread } \\
\text { nationally, with } \\
\text { greater concentration } \\
\text { in SP, MG, and } \\
\text { Southern Brazil }\end{array}$} \\
\hline 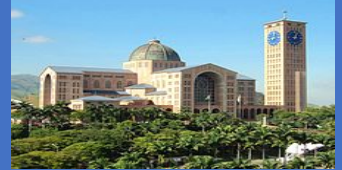 & & & \\
\hline & \multirow[b]{2}{*}{$\begin{array}{c}\text { Macro- } \\
\text { Regionof the } \\
\text { Brazilian } \\
\text { Amazon }\end{array}$} & \multirow[b]{2}{*}{$\begin{array}{l}\text { Mediatic-Ecosystem } \\
\text { (Advertising) due to the } \\
\text { force of diffusion of } \\
\text { assets in material and } \\
\text { immaterial records }\end{array}$} & \multirow[b]{2}{*}{$\begin{array}{l}27 \text { Festivity-Capitals. } \\
\text { Influenced by the } \\
\text { Círio de Nazaré, but } \\
\text { also reinvented in } \\
\text { other saints }\end{array}$} \\
\hline$\frac{1}{17}$ & & & \\
\hline Das Dores & \multirow[b]{2}{*}{$\begin{array}{c}\text { Micro-Region } \\
\text { of Northeast } \\
\text { Brazil }\end{array}$} & \multirow[b]{2}{*}{$\begin{array}{l}\text { Mythic-Religious (of } \\
\text { Celebration) because of } \\
\text { the stories of conflict } \\
\text { and resistance to the } \\
\text { conformation of the } \\
\text { traditions in popular } \\
\text { Catholicism }\end{array}$} & \multirow[b]{2}{*}{$\begin{array}{l}35 \text { Representations of } \\
\text { American Latinity. } \\
\text { Considering the } \\
\text { density of the conflicts } \\
\text { within the continental } \\
\text { religious heritage. }\end{array}$} \\
\hline 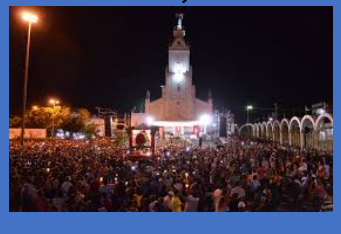 & & & \\
\hline
\end{tabular}

Figure 1. Three models of shrines and their irradiation vectors. Source: Elaborated by the author (2017). 
Taking into account the greater development, so far, of the records over the vectors of the devotional network from 38 municipalities that were promoted to N.S. da Conceição shrines (see the systematization of these municipalities on the project's website http://www.santuario.ufc.br/mariana/) enabled us to identify a consistent associative/competitive dynamic of the three vectors.

Basically, two predominant tendencies were observed in the way of understanding the use of symbolic vectors to promote the irradiation of this Marian devotion in its territory of influence [13]. The first, corresponding to the mirrored project and inspired by the "standard" shrine in Aparecida (SP), associates the other vector forces, from the most representative vector of the civic-republican negotiations: the political-tourist, responsible for the visitation organization(devotional or cultural). These municipalities have a small population, as shown in the demographic table below. Ourinhos (SP), with its 111,000 inhabitants, delimits the maximum size in which this vector balance is manifested. The map of Marians invocations (Figure 2) initially identifies such municipalities, showing their concentration on the supra-regional scale, with a predominance of states of South-Central Brazil.

From then on, we considered the grouping of information from two sources accumulated in the course of the research. First, the visit to the municipalities of the state of São Paulo, along with the field activities held, always in the second semesters of 2014, 2015, and 2016. These totaled nine municipalities visited, with their structures observed for religious festivity and the tourist reception of devotees and pilgrims.

Besides Aparecida, we also visited Ourinhos, Ribeirão Preto, Bauru, Sorocaba, Jundiaí, Itapetininga, Tambaú, and Ribeirão Preto. In other states of Brazil, taking advantage of the travel opportunities but not exclusively linked to this research, we were also able to visit the shrines at the invocation of Conceição/ Aparecida in Belo Horizonte (state of Minas Gerais), Florianópolis (Santa Catarina state), São Luís (State of Maranhão); and the municipalities of Pedra de Fogo and João Pessoa (both in State of Paraíba).

This predominance of capitals, completing the survey in the 14 cities visited, allowed us to predict the second tendency, whose characterization was better delineated in the survey that cross-referenced secondary information from digital sources. Table 1 lists the main items we considered to analyze and classify such sources. Figure 3 summarizes the results of this classification: It indicates that the second tendency represents a greater rivalry between the symbolic vectors, associated with the processes of configuration of religious patrimonies that are more similar to two other Marian shrines in the North and Northeast of Brazil. Sometimes, mediatic-ecosystemic predominance emerges, similar to the process we decoded in Círio de Nazaré, Belém (state of Pará) while at other times mythical-religious vector leadership is manifested, as in Juazeiro do Norte (state of Ceará). Both represent syncretic values, which are relatively tense and deep in the design of popular Catholicism, although manifested in cities much larger 


\section{Spatial distribution of the shrines of Our Lady of Conceição Aparecida in Brazil}

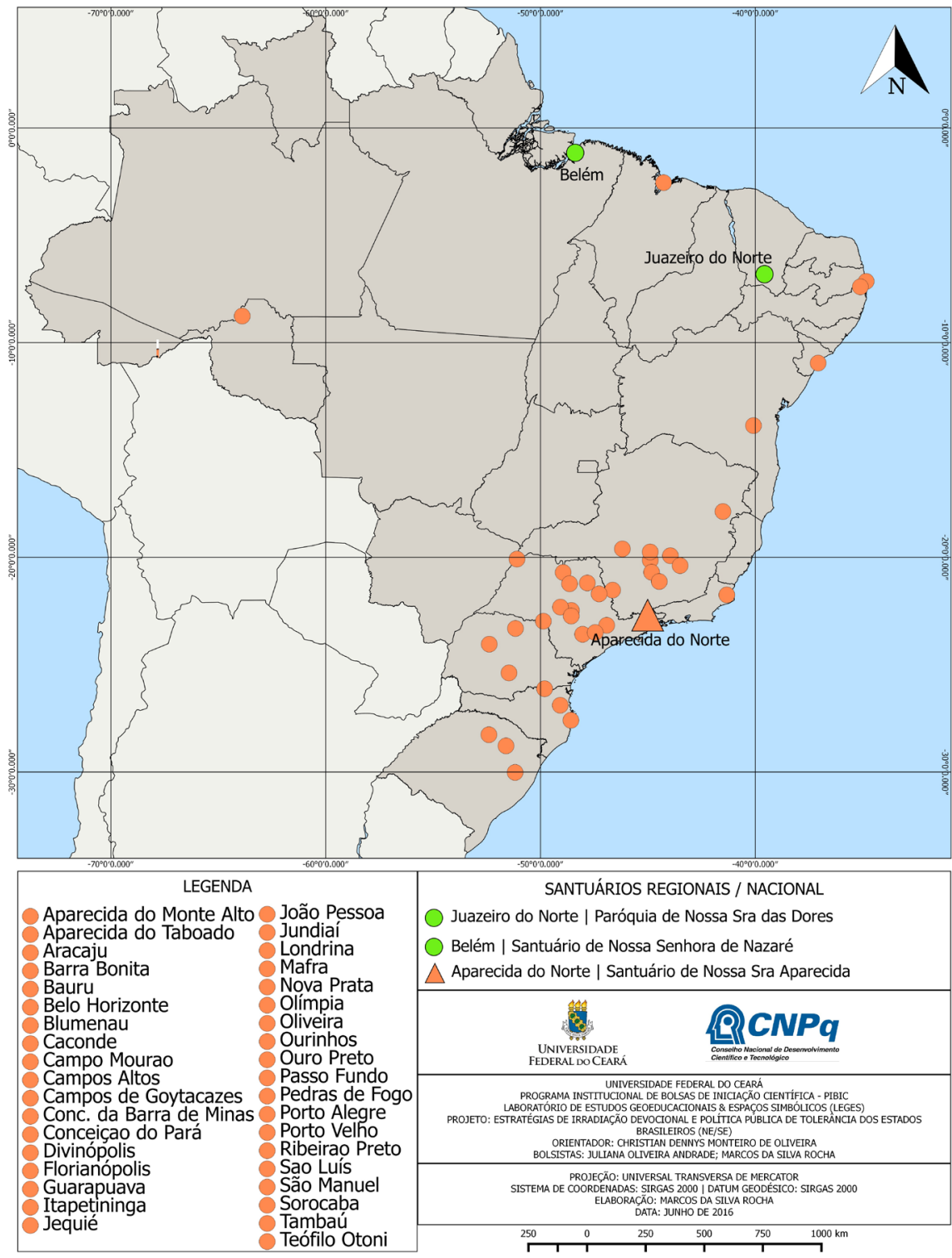

Figure 2. Shrines of Invocation to O. L. of Conceição in the Brazilian territory. Source: LEGES collection (2016).

than Aparecida. Hence, the "descending" (not harmonious) comprehension of the vector process.

The correlation of these 13 items that complete our database for shrine municipalities was also elaborated in consideration of the lack of information (source gaps), especially in locations with a lower economic-regional and demographic size. This reinforces the condition of "collaboration" of the vectors in localities of up to 100,000 inhabitants. In these cases, the field visit in 14 of the 38 localities comprised an exercise tostrengthen the observation of the urban, ecclesial, and aesthetic/administrative structures inherited from the process of consolidation of the shrine in the municipal fabric. Therefore, the intention was not to 
Table 1. Items surveyed in the database construction.

\begin{tabular}{ll}
\hline \multicolumn{1}{c}{$\begin{array}{c}\text { SYMBOLIC VECTOR } \\
\text { ANALYZED }\end{array}$} & \multicolumn{1}{c}{ ITEM LINKED TO THE DATABASE } \\
\hline $\begin{array}{l}\text { Political-Tourist } \\
\text { (Devotees in visitation) }\end{array}$ & $\begin{array}{l}\text { News and municipal information (IBGE) Civic Festivities } \\
\text { Schedule Municipal population/Income per capita Tourist } \\
\text { and entertainment services companies }\end{array}$ \\
$\begin{array}{l}\text { Mediatic-Ecosystem } \\
\text { (Advertising ceremonies } \\
\text { in mediatization) }\end{array}$ & $\begin{array}{l}\text { Social and environmental news and information Thematic } \\
\text { festivities in the cities or districts Scientific works about the } \\
\text { place or region Local media }\end{array}$ \\
$\begin{array}{l}\text { Mythical-Religious } \\
\text { (Rituals in carnivalization) }\end{array}$ & $\begin{array}{l}\text { News and information on religious events Images of the } \\
\text { patron's feasts Website of the shrine Other } \\
\text { religions/Non-Catholic featured confessions Videos of the } \\
\text { festivities during the Our Lady of Conceição Festivity }\end{array}$ \\
\hline
\end{tabular}

Source: Elaborated by the author (2016).

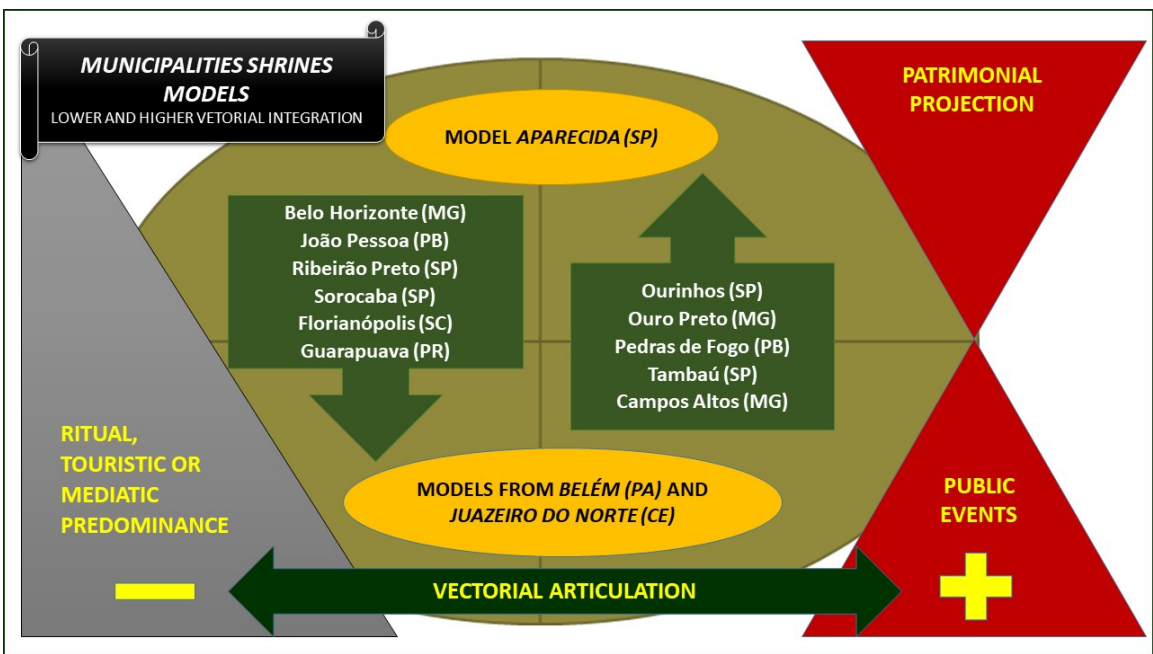

Figure 3. Typology of shrine municipalities. Source: Elaborated by the author (2016).

observe the devotional event as a means to size it in terms of its cultural impacts on the city, neighborhood, or district. Rather, it was merely to note the diversity of inclusive landscape forms, or of the "shrine" place in the "municipality" space, or, conversely, by a set of symbolic representations, the municipality place in the shrine space.

This inversion projects and feeds the parameter of the Aparecida geographical model, when expressing how the shrine is born in a municipal periphery (Guaratinguetá), creates local identity until it becomes a devotional reference (Aparecida autonomy), and in the monumentality of its spectacular construction, recreates all the spatiality of services within the shrine itself (Metropolitan Complex of the New Basilica). The photos of Pedra de Fogo (Paraíba), RibeirãoPreto, and Sorocaba (São Paulo)-Figure 4-point to the projection of these "Aparecida stages" in the configuration of the emerging heritage in these municipalities. It is necessary to consider, later, what the limits of the public representation of these shrines are capable of articulating in terms of the religious specificity of the Christian communities to the non-excluding cultural access of the diversity 

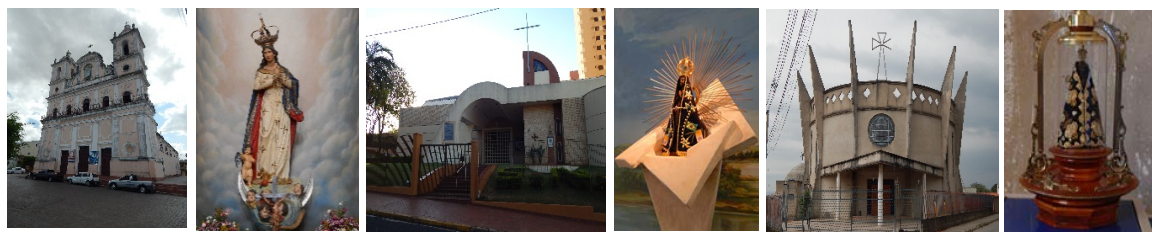

Figure 4. Shrines and saints (Conceição Aparecida) diversifying the irradiation. Source: LEGES Collection (2016).

of non-Catholic groups. We now deal with the theoretical challenge of the vectorial inversion of the symbolic irradiation forces promoted by the aesthetic play of images of Marian devotional landscapes. The scenarios (internal/external) of the urban theatricality of shrines multiply the patrimonial value of the localities in diverse traditions.

These scenarios, geographically updated in the patrimonial process, are centers of formation of a very complex network of connections, since it is already ready (inherited), in tessitura (incomplete) and, at the same time, in full dilution with the signs of terrestrial diversity (telluric syncretism).

\section{Irradiation by Vector Inversion: Challenges to the Network of Shrine Municipalities}

Moving from vector models, aggregators of the forces of visitation, communication, and ritualization, to a systematically reverse design, is apparently to "deny" the symbolic phenomenon of devotional irradiation in a single movement: inversion. However, appearances, when they do not deceive, demonstrate the power of reflective models, even when qualitative research drives the research process. In our case, this established is by the procedural antinomy of Christian doctrines, which radicalize the theistic (divine) path as unique to human salvation at the same time-space in which they promote, encourage, and absorb $\mathrm{Ma}$ rian corporeality as an indispensable image of the grace of God.

One can recover the game of appearances in the subtlety of the prophetic interpretation of sociologist Jean-Marie Guyau (1854-1888) [14]. In his treatise on the postmodern tendencies of religion-The Irreligion of the Future: Sociological Study-he works in the final chapters on metaphysical hypotheses, or in other words, on systems of values that are rationally credible and capable of replacing the irrational or illusory powers of devotions:

After the Stoics and Kant, a kind of orientation of all metaphysical hypotheses was produced. What is today the greatest attraction of these hypotheses is that they tend to give moral sense to the world, to give universal evolution a direction that is in conformity with that of our consciousness as social and affectionate beings. The future history of religions is summed up in the law that religious dogmas, first transformed into simple metaphysical conjectures and later reduced to a certain number of hypotheses among which each individual will make an ever more rational choice, will eventually prioritize especially the moral problem: religious metaphysics will end up being, above all, a transcendent mor- 
al, an ideal sociology encompassing all beings that make up the universe [14].

The projection-response of a "moral" conduct to the sociological transformations of humanity, under the sign of modernity, tends to ignore the explosive conjuncture of the geographic transformations emerging in the Western world in the last 150 years. By a scientific refinement of craft, we read the predominance of another conduct: aesthetics. Not only because Guyau's pantheistic irreligion was programmed into the insubordinate fabric of religions, philosophies, sciences, and sects, but, by the special orchestration of what Gilles Lipovetsky and Jean Serroy [15] call hypermodernity, because it was moved to the basis of the absolute aestheticization of capitalism in the twenty-first century. The authors re-compose the traditional perception of religious space into the extroverted logic of spectacle and amusement.

In the era of artist capitalism, hyper-spectacle, consumption, and fun form the system. Fun is no longer a marginal and separate domain; it has become a fundamental economic sector, a trans esthetic industry that grows every day. Today the universe of entertainment extends well beyond the cinema, television, and music; it encompasses objects, games, information, communication, cities, commercial spaces, museums, heritage and even national celebrations. Fun is no longer opposed to economics or everyday life; in the reign of creative capitalism; it infiltrates all spaces of life and merges with the market. We are in the era of integrated and generalized fun, marked by the hybridization of commodity, emotion and mass distraction [15].

Gigantism, visual shock, sonic and linguistic provocations, the escalation of violence, and celebrity worship are present both in the concepts of analysis of the hyperspectral and the forms of symbolic reading of the Marian shrines' theatricality. It is precisely the sum of theatrical forces-time/space/movement-that Pavis [2] termed "vectors", and then we allow analytical overreaching to affirm that devotional irradiation occurs through inversion: as ritual myths, advertising media, and tourism migrations are emanated from the ethical-religious energy of the shrine, devotional understanding depends on an emergence or emanating from aesthetics. Without beauty-and that of the Virgin Mary, festively and amusingly - the density of the Christian message no longer holds.

In these terms, it is important to think in terms of acounter-vector, in other words, an inverted vector of poetics as the theatricality of devotional knowing, which gives substance to the conception of the cultural and religious system, converted into a "geosymbol" of territoriality in the perspective of geographer Joël Bonnemaison. In researching the "in-exodus" rooting of the Jews to the expectation of returning to Jerusalem (terrestrial or celestial), Bonnemaison indicates, by means of religion, the functional metaphor of geography as the Promised Land. According to Paul Claval:

An important part of the identity of non-geographic societies, in the sense of Joël Bonnemaison, finds its foundations in religions: this time they are revealed religions, not polytheisms or animisms, that locate beings and divine forces in plants, stones Or beings. In modern times, identities appear increasingly depen- 
dent on the ideologies of progress and the philosophies of history. The study of the feelings of identity and territoriality is then strongly linked to that of religions [16].

Such geographical feelings, projected onto the religious imaginary, demand events, celebrations, and sacred acts in time and space made sacred by the double meaning of their staging. This is the theater of faith, which enshrines, condenses, reveals, and conceals in its aesthetic duplicity the brilliant alertness of Antonie Artaud in dealing with the pulsating aesthetics of theatrical language:

Considered from this angle, the objective work of the re-enactment reassumes a kind of intellectual dignity through the fading of the words behind the gestures and the fact that the plastic and aesthetic part of the theater abandon its character of decorative interlude to become, in the proper sense of the word, a directly communicative language... In short, the theater must become a kind of experimental demonstration of the profound identity between the concrete and the abstract [17].

The inverted vectors of festive aesthetics in the spectacles of Marian praise are games of concrete spiritual idealization and abstract terrestrial materiality. Ecclesial scenarios of strange (but desired) architectures welcome in and out scenes of reconciliation of the multiple and restless ways of creating the divine/human (in the venter or lap) of Mother Earth. Just as in the paired expressions in Figure 3, the Marian images materialize the aesthetics of theatrical games, by inverting the scene to the scene, whether in the "destructive" frequency denounced by the radical consumerism of values of the "aesthetics of the hypermodern world", which is mostly excluding; or in the "constructive" frequency, usually inclusive, in the promotion of festive shrines and integrators of religious events in a geographic network of celebrations.

Precisely for this reason, the shrine municipalities (we of this interrupted communication) anticipate or evoke a continental network of tensions/conciliations at scale. They design a Shrine Continent to forge in the symbolic terrestrial space a matergraphy of religious heritage. The municipal "stages" of the shrines behave like scenic prophecies of reception of the senses of vectorial forces (visitor, mediatizing and ritualistic) and counter-vectors (of aesthetic inversions, spectacular and theatrical), as we try to schematize in Figure 5 (Schemas). The idea of using a schema synthesis is to operate an update of Figure 3 that involves (and re-adapts) other similar studies in the different nationalities of the continent, with the aim of expanding the space-time network that the reference shrines, with their smaller projections in the interior and larger articulations in capitals and metropolises, evoke.

\section{The Matergraphy in the Bookkeeping of Continental Latinity}

The aesthetic radicalization of patrimonial forms, as a reaction force or response to the symbolic vectors, leads to the widening of our gaze towards the continental scale. We consider this an inductive exercise of the interpretative work, a 


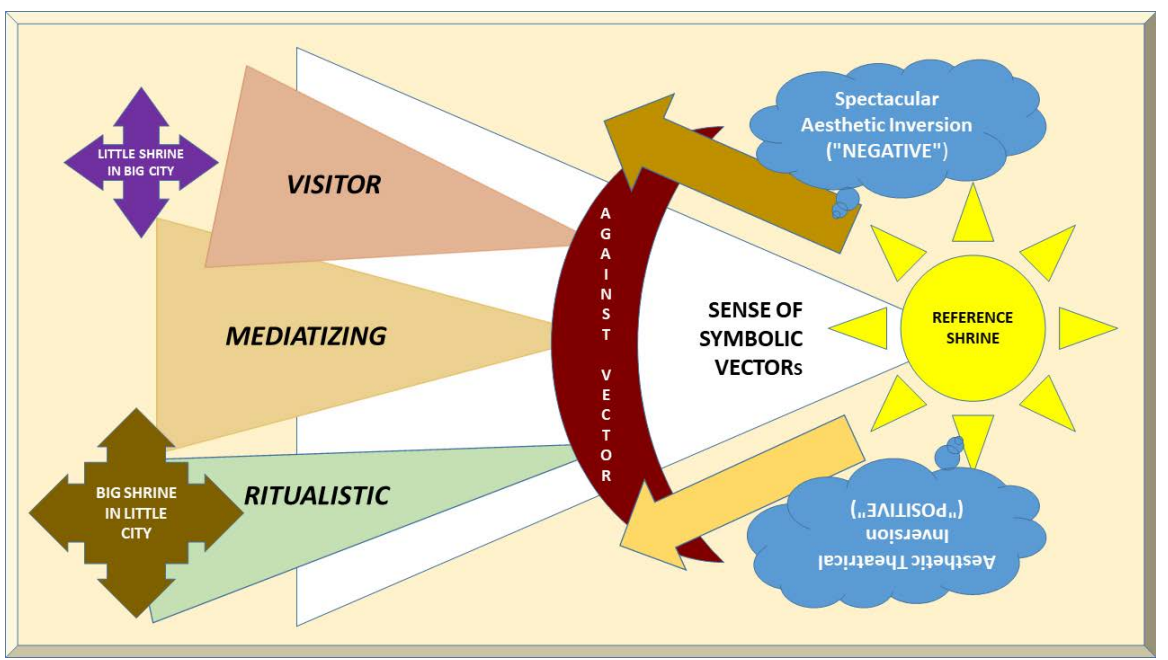

Figure 5. $3 \times 1$ Schemas of vector forces and their counter vector. Source: Elaborated by the author (2017).

hermeneutic of the shrines, in continuity with the epistemological exercise that we began three years ago, in investigating the implications of the representative places and their Marian shrines. We indicate two epistemologies in the process of geographical understanding of the continent, in view of its Latinity as a communicational culture of unification.

By the bias of cultural traditions materialized in inherited goods, we will call the first one Matergraphy. In complementation, considering the new cybernetic connections (or projected goods), we will call the second by the neologism of Theopolyphonia. The devotions preliminarily located here, in distinct types of Latin American shrines, tend to form, therefore, a set of goods inherited and projected as geo-educational models of communication. The work, based on the following item, forms a scientific model for learning the terrestrial system through graphic or literary images, based on the creative imagination of Bachelard. Earth is taught as Gaia; however, their learning is inherited from a motherly understanding. On the other hand, the second epistemological model, theopolyphonia, centered on Bakhtin's dialogism, corresponds to a teaching philosophy that demands religious sensitivity. In this sense, the Earth is learned as Portal: the Kingdom of God, the Earth Without Males, Mystic Africa or Nirvana, among so many possibilities. In any case, understanding is predominantly paternal [18].

In handling these typologies of maternal and paternal symbolism-as parameters of learning (host house) and teaching (travel portal) - , both Bachelard's Imagination and Bakhtin's Dialogism allow us to extrapolate the reading of Brazilian Marian shrines in another 20 similar models, mirrored by countries of the American continent, where Catholicism, with greater or lesser force, has forged a patrimonial space. The matergraphy and theopolyphonia, respectively, condition and project the flow of the patrimonial values that the vectorial inversion causes to emerge, especially when it comes to recognizing in those places the 
planning of the impossibility of investment in the demarcation of a Latin American culture, with continental macro-coverage, without the participation of shrine places in regional and national forms of representation [19].

In deciding whether to characterize the resistance of Cuban and Venezuelan societies, including their socialisms, whether to demonstrate Canadian or North American multi-cultural complexity, or even to expose the mercantilization of the emerging Argentine, Chilean, and Brazilian economies, one must consider the nationally-sanctioned municipalities as connectors of a religious, Christian, and Western ideology. So...America is Latin too because it continues to be drawn into Marian devotional principles, and beyond that of the Catholic moorings of this origin and management, the patrimonial dimension of Latinity cannot ignore such geography.

The selection that characterizes Table 2 was established by the permanence of a representative and inheritance of the "Catholic states" (including Anglican Catholicism), which are demarcators of the republics of the Far West. The list does not include all 35 independent countries, as it privileged access to a website or blog that would allow the reader to have relatively up-to-date information on the Marian devotional system plus recognition (nationally) with national patronage.

A visit to the official origins, historical processes, and publicity effects of the national Marian images, points to the necessity of a universe of specificities in the context of each nationality. It is not a matter of detailing how similar invocation virgins are-as in the example of the invocation to the Conception in Argentina, Paraguay, Nicaragua, and the United States-to project local specificities and modulate the equivalences of regional/national autonomy, thus multiplying the devotion to Aparecida [20]. After all, even when the Mexican Virgin of Guadalupe renews the myth of the origin of the Spanish Guadalupe in another nationality, nothing prevents it from being understood in exclusivity and being projected in the continental approach.

Since Guadalupe is the patron saint of Latin America, considering the cosmopolitan weight of the shrine municipality (the Mexican capital itself and the Aztec empire), one can point out the reticular expressiveness of lines of interpretation for each devotional panorama. To what extent are there "miraculous" fisheries, incidents with "images", historical libertarian events, visions and celebrations of "epic" or "tragic" episodes, or prints, as the mantle of the Santo Indígena Juanito (visionary of Our Lady), atheophonic (didactic) narrative for the same matergraphic understanding (in meaningful learning)? Perhaps, as the studies reveal so far, it is not possible to treat the apparitions of Marianas only as a religious tourist attraction of the Gordian knots that embarrass Christianity/paganism along the paths that have sanctified the character of Mary, the mother of Jesus [21] [22]. The most plausible would be to answer the question, to what extent is it possible, by multiplying points and weaving Latin Continentality, to reinterpret agents and identifying elements of the $3 \times 1$ forces, 
Table 2. National devotions with reasonably available information.

\begin{tabular}{|c|c|c|c|}
\hline \multirow{2}{*}{$\begin{array}{l}\text { SHRINE OF THE } \\
\text { PATRONAGE } \\
\text { Shrine/Devotion }\end{array}$} & \multicolumn{2}{|c|}{$\begin{array}{l}21 \text { MUNICIPALITIES AND } \\
\text { NATIONS OF THE } 3 \\
\text { AMERICAS }\end{array}$} & \multirow{2}{*}{$\begin{array}{c}\text { SHRINE WEBSITE } \\
\text { Website/Blog with detailed information }\end{array}$} \\
\hline & City & Country & \\
\hline NS de C. de Lujan & Lujan & ARGENTINA & http://www.basilicadelujan.org.ar/ \\
\hline NS de Copacabana & Copacabana & BOLIVIA & $\begin{array}{l}\text { http://forosdelavirgen.org/193/nuestra-senora-de-la-candelaria-de-copacabana-bolivi } \\
\text { a-5-de-agosto/ }\end{array}$ \\
\hline NS da C. Aparecida & Aparecida (SP) & BRAZIL & http://www.a12.com/ \\
\hline NS do Rosário & Cap Madalaine & CANADA & https://www.sanctuaire-ndc.ca/en \\
\hline NS del Carmem & Santiago & CHILE & http://www.virgendelcarmen.cl/vdc-en-la-historia-de-chile.php \\
\hline NS del Rosário & Chiquinquirá & COLOMBIA & http://virgendechiquinquira.com/ \\
\hline NS de Los Angeles & Cartago & COSTA RICA & http://forosdelavirgen.org/188/nuestra-senora-de-los-angeles-costa-rica-2-de-agosto/ \\
\hline NS da Caridade & El Cobre & CUBA & $\begin{array}{l}\text { https://www.ecured.cu/Santuario_de_Nuestra_Se\%C3\%B1ora_de_la_Virgen_de_la_ } \\
\text { Caridad_del_Cobre }\end{array}$ \\
\hline NS da Paz & San Miguel & EL SALVADOR & http://www.reinadelcielo.org/nuestra-senora-de-la-paz-patrona-de-el-salvador/ \\
\hline NS del Quinche & Quito & ECUADOR & $\begin{array}{l}\text { http://forosdelavirgen.org/395/nuestra-senora-de-la-presentacion-del-quinche-ecuad } \\
\text { or-21-de-noviembre/ }\end{array}$ \\
\hline NS da Conceição & Washington & USA & http://www.nationalshrine.com/site/c.osJRKVPBJnH/b.4719297/k.BF65/Home.htm \\
\hline NS do Rosário & Guatemala & GUATEMALA & http://forosdelavirgen.org/327/nuestra-senora-del-rosario-guatemala-7-de-octubre/ \\
\hline NS de Concepción & Suyapa & HONDURAS & $\begin{array}{l}\text { http://forosdelavirgen.org/529/nuestra-senora-de-la-concepcion-de-suyapa-hondura } \\
\text { s-3-de-febrero/ }\end{array}$ \\
\hline NS de Guadalupe & México & MEXICO & http://basilica.mxv.mx/web1/-home/index.html \\
\hline NS de Concepción & El Viejo & NICARAGUA & $\underline{\text { http://www.corazones.org/maria/america/nica_inmaculada_viejo.htm }}$ \\
\hline NS de La Antigua & Panamá City & PANAMA & http://forosdelavirgen.org/266/santa-maria-la-antigua-panama-9-de-septiembre/ \\
\hline NS de Caacupé & Caacupé & PARAGUAY & $\begin{array}{l}\text { http://forosdelavirgen.org/415/nuestra-senora-de-los-milagros-de-caacupe-paraguay } \\
\underline{-8 \text {-de-diciembre/ }}\end{array}$ \\
\hline NS das Mercês & Lima & PERU & http://forosdelavirgen.org/286/nuestra-senora-de-la-merced-peru-24-de-septiembre/ \\
\hline NS de Altagracia & Higuey & $\begin{array}{l}\text { DOMINICAN } \\
\text { REPUBLIC }\end{array}$ & http://www.basilicahiguey.com/index.php \\
\hline NS de los 33 & Montevideo & URUGUAY & http://forosdelavirgen.org/376/virgen-de-los-treinta-y-tres-uruguay-8-de-noviembre/ \\
\hline NS de Coromoto & Guanare & VENEZUELA & http://www.santuariobasilicacoromoto.com/SNCoromotoWeb/history1 \\
\hline
\end{tabular}

Source: Elaborated by the author (2017).

composed from the figure discussed above. The challenge to work on the long list of Latin American countries is now open.

\section{Conclusion: Fundamentalist Risks of Matricide in Religious Heritage}

The path covered by this winding article would not be compromised by the interpretation of the geographic network that we have named the matergraphy of religious heritage if we did not allow the problems of the overflowing of symbolic Marian Catholicism in political-ideological Catholicism to emerge. The contemporary context of exacerbating the rights to diversity and religious pluralism 
signals advances in the social capacity to "do the right thing" as a parameter of moral responsibility. This takes into account the fair warnings outlined by philosopher Michel Sandel [23] when it includes the importance of obligations of solidarity between natural duties and individual and voluntary issues.

Unlike natural duties, the obligations of solidarity are private, not universal; they involve moral responsibilities that we should have not only with rational beings but with those who share a particular history. However, unlike voluntary obligations, they do not depend on an act of consent. Its moral value is based, instead, on the localized aspect of moral reflection, on the recognition of the fact that my life history is implied in the history of other individuals [23].

It is precisely the intermediary path of the obligations of solidarity, readapted to the plans of duplicity-matrice, as far as the origin of Christianity and theatr$i c a l$, in the aesthetic game of the inversion of symbolic vectors-that is obstructed when the experience of the Marian Shrines is claimed as the nucleation of Latin American cultural heritage. Although the inventories of tipping (material) and safeguarding (immaterial) recommended by the Brazilian Institute of National Historical and Artistic Heritage (IPHAN) in Brazil, follow UNESCO's standards of care for the promotion of social diversity, it remains a risky resistance, whose conflict leads to two models of what we here call matricide. On the one hand, there is the theological and mercadological rompante, in the face of Catholic hegemony, that is capable of erecting devotion to Our Lady as a radical riddle of Catholic identity. This is reflected in the exaggerations of the spectacular aesthetics of the Virgin cult, deprived of its role as mediator of the devotional reach to the Holy Trinity, to assume the vanguard of acceptance that Catholicism would be a religion with practices different from other forms of Christianity, which are ignorant or distrustful of the dogmatic power of Mary. To remind us that this force of Marian devotion promotes a strategic action to maintain Catholic hegemony in places with no room for negotiation, the historian Mauricio Aquino [24] presents a whole narrative of local adaptation. His study shows how the patrimonialization of the diocesan shrine incorporated icons and figurations into institutional emblems of the municipality of Ourinhos to celebrate, in 2004, the 50 years of his mariofania (expression of the author). The intact image of Aparecida was rescued from a train car in a fire that occurred in July 1954. Marian cults events, celebrations, and great festivities-such as the Marian Year of 2017 to mark the 300th anniversary of the discovery of the image of Conceição Aparecida, in São Paulo (Brazil, 1717) and of the 100 years of the apparition of the Virgin of the Rosary of Fatima (Portugal, 1917). Those celebrations open the space for reverse postures, without any explicit form of ecumenical inclusion or mechanisms of tolerance and effective participation for those from other religious traditions [25].

The other side, therefore, could be recognized as a refusal or escape from Marianism-a marianophobia, perhaps-, whose immediate effect is the charge of heresy, from other Christians to Catholics, for deifying a woman as the Mother of God, at the same time that every syncretic facility of the Marian figure draws 
links of religious simultaneity. After all, a Marianism open to the interpretation of solidarity morality, which moves the cosmopolitan tessitura of the cities, metropolises, and Western communities, allows a Christian Republican to practiceIslamism, Hinduism, Buddhism, Shamanism, animism, indigenism, and Umbandism, amongst many other creeds, since it is moved by the active piety of humanistic acceptance. To a certain extent, it is this breadth of contemporary maternal practices that repels the most fundamentalist representatives of other systems. It also helps in the intercontinental negotiation of the various refugee crises on the planet. Such a structure, even in its contradictions, agglutinates the great social mass of indigenous and African descendants, practitioners of cults forged in the theatrical composition of tribes, quilombos, and terreiros, usually on the margins of elitist centers, found in Latin American Marian shrines, micro or macro special conditions of manifestation, and socio-cultural challenge.

The set of festivities, which revolve around the homage of the Peoples of Tradition to the Mother of Nationality in the countries of the continent, is, therefore, an easy target for a geographic matricide. A fundamentalist act that prunes, when it does not literally kill, the most representative elements of the principles of Laicity, forms the basis of the connection between the Geography of Marian Symbols (or Matergraphy) and the Space/Time Valorization of Cultures or Heritage.

Aware that this study, which is partially closed, still needs to contemplate the stages of effective comparison of Marian devotion with other celebrations (Christian and non-Christian) in the continent, we consider the idea of reinforcing some of the points treated, without which the reticular space of the shrine municipalities would not be strengthened.

1) MATERGRAPHY can continue to be an instrument of analysis of the symbolic learning of religious cultural systems, provided it is not restricted to thinking that the Marian Devotion of Catholicism is the only model or standard of reverence for the Earth, Nature, and the spiritual forces that promote them. Despite all efforts to understand the Shrines of Conceição Aparecida, at no time did this study seek to restrict the conception of Matergraphy to the Catholic model of worship of Senhora da Conceição. Scientifically, the second is just a possible example of the complexity of the former, and, as has been seen, it gives us great possibilities of geographical interpretation;

2) HERITAGE - in its cultural, religious, and predominantly immaterial cut-must remain a field of identity debate and a growing source of approximation of the geography of artistic languages (especially theatrical). From this condition, we can think of the patrimonial issue as a thematic fuel for the impulsion of symbolic vectorial forces, those forces without which a relational analysis of the Marian spaces, whether internal or external, remains limited to ecclesial circuits.

3) The SHRINE MUNICIPALITIES correspond to the places symbolic of an unsurpassable fusion (and confusion) of political powers (secular and ecclesial), whose tendency is to imitate, in the game of time and space 
communicational (chronotopy) the great Marian shrines of the Latin American continent. The tensions in its complexity and abundance of space reach different formal scales, forcing a geography of communications to systematically consider the category space-time network for religious movements in spaces of greater technical density: State capitals (in Brazil) and national capitals (in the American continent).

We plan to study the Capital-festivities in continuity to the bonds between matergraphy and heritage, highlighting shrine municipalities with greater official regional representativeness and also examining the secular challenge of considering its organizational specificities and its conviviality with other celebrations, both Christian and non-Christian. These are the future directions in which the bachelardian discussion, on the founding "study", will take us henceforth.

\section{Special Thanks to}

The National Council for Scientific and Technological Development (CNPq), which financed the productivity research grant and the Universal Call for Proposals, approved in 2014 (Universal Call - MCTI/CNPq-14/2013), under the title STRATEGIES OF MARIANA DEVOTIONAL IRRADIATION: Formation of Database and Images in the Typology of Municipalities-Shrine as a subsidy to the Policy of Religious Heritage; To the Coordination of Improvement of Personnel of Higher Education - CAPES, which stimulated the direct link of this work with the Postgraduate Program in Geography of the Department of Geography of the UFC; and To the UFC-Federal University of Ceará and ADUFCUnion of Federal Universities of the State of Ceara that provided the conditions to present the work at the 34th meeting of CLAG in New Orleans.

\section{References}

[1] Bachelard, G. (2008) Studies. Contraponto Editora, São Paulo.

[2] Pavis, P. (2008) Analysis of the Shows: Theater, Mimica, Dance, Dance-Theater, Movietheater. Perspectiva, São Paulo.

[3] Kozel, S. (2013) A Panorama on Marginal Geographies in Brazil. In: Heidrich, Costa and Pires, Eds., Ways to Read Geography and Culture, Porto Alegre, Press Free, Compass Place Culture, 12/27.

https://laboter.iesa.ufg.br/up/214/o/MANEIRAS_DE_LER_GEOGRAFIA_E_CULT URAL.pdf

[4] Oliveira, C.D.M. (2012) Party Paths to the Geoeducational Heritage: How to Educate without Staging Geography? Publisher of UFC, Fortaleza.

[5] Ferrara, L.D.A. (2008) Communication, Space and Culture. Annablum, São Paulo.

[6] Eliade, M. (2001) The Sacred and the Profane: The Essence of Religions. Translator: Rogerio Fernandes. Martins Fontes, São Paulo.

[7] Gil Filho, S.F. (2008) Sacred Space, Studies in Geography of Religion. IBPEX, Curitiba.

[8] Santos, B.S. (2014) If God Were a Human Rights Activist. Cortez, São Paulo.

[9] Claval, P. (1996) Religion et Ideologie. Perspectives Geographiques. Press from 
l'Universite Paris-Sorbonne, Paris.

[10] Ruiz, C.B. (2004) The Paradoxes of the Imaginary. Ed. Unisinos, São Leopoldo.

[11] Murad, A. (2012) Mary, All of God and So Human: Compendium of Mariology. Paulinas; Sanctuary (Peregrina Collection in Faith), Sao Paulo.

[12] Certeau, M. (1990) The Practice of Everyday Life: 1. Arts of Making. Voices, Petropolis.

[13] Santos, M. and da Graça, M.P. (2006) Spirituality, Tourism and Territory: Study Geographical of Fatima. Principia, Estoril.

[14] Guyau, J.M. (2014) The Irreligion of the Future: Sociological Study. Martins Fontes, Sao Paulo.

[15] Lipovetsky, G. and Serroy, J. (2015) The Estetization of the Mundo, Living in the Age of Capitalism Artist. Companhia das Letras, São Paulo.

[16] Claval, P. (2003) The Recent Evolution of the Geography of the French Language. [The Recent Evolution of French-Speaking Cultural Geography.] Geosul, 18. https://periodicos.ufsc.br/index.php/geosul/article/viewFile/13599/12466

[17] Artaud, A.M.J. (2006) The Theater and Its Double. Martins Editora, São Paulo.

[18] Oliveira, C., Araujo, J. and Tavares, K. (2016) Geoeducational Heritage in Formation Symbolic of Municipalities-Sanctuaries in South America. GEOSABERES Revista Geoeducational Studies, North America.

[19] Sa, C.P. (1996) Central Nucleus of Social Representations. Ed. Vozes, Petropolis.

[20] Oliveira, C.D.M. (2001) Basilica de Aparecida: A Temple to the City-Mother. Olho D’água, São Paulo.

[21] Alvarez, R. (2015) Maria: The Biography of the Woman Who Generated the Most Important Man of History, Lived a Hell, Divided the Christians, Conquered Half the World and Called Mother of God. Globo, Sao Paulo.

[22] Steil, C.A., Mariz, C.L. and Reensink, M.L. (2003) Mary among the Living: Reflections Theories about the Marian Apparitions in Brazil. Publisher of UFRGS, Porto Alegre.

[23] Sandel, M.J. (2016) Justice: What's the Right Thing to Do? Brazilian Civilization, Rio de January.

[24] Aquino, M. (2011) History and Devocao: The Social Construction of the Worship of Our Lady Aparecida do Vagao Queimado de Ourinhos-SP (1954-2004). EDUSC, Bauru-SP.

[25] Sanchez, W.L. (2010) Religious Pluralism: The Religions in Today's World. Paulinas, São Paulo. 